\title{
Stand structure, competition and growth of Scots pine (Pinus sylvestris L.) in a Mediterranean mountainous environment
}

\author{
Antonio García-Abril, Susana Martin-Fernández, M. Angeles Grande, Jose A. ManZAnERA*
}

Technical University of Madrid (UPM), Research Group for Sustainable Management, E.T.S.I. Montes, Ciudad Universitaria s.n., 28040 Madrid, Spain

(Received 19 January 2007; accepted 4 May 2007)

\begin{abstract}
The relationship between competition and tree growth was studied in four stands of Pinus sylvestris L. occurring in a continental Mediterranean mountain area (in the Guadarrama range, Spain), i.e., an uneven-aged stand, a stand with oak (Quercus pyrenaica Willd.) understorey, a plantation, and a mature even-aged stand. Competition was measured by a simple size-ratio distance-independent index and was negatively associated with tree diameter. This negative association was stronger in the uneven-aged, plantation and mature even-aged stands than in the stand with oak understorey. Competition was also negatively associated with current diameter increment. This relationship was moderately strong in the mature even-aged stand and weak in the uneven-aged stand and the plantation. In the uneven-aged and the mature even-aged stands, a weakly significant relationship was found between diameter growth and tree size, whereas these parameters were not associated in the stand with oak understorey. The competition index provided a better prediction of growth rate than the alternative use of diameter. Both diameter and basal area growth were greater in the uneven-aged than in the even-aged stands.
\end{abstract}

competition / growth / Pinus sylvestris / Scots pine / stand structure

Résumé - Structure des peuplements, compétition et croissance du pin sylvestre (Pinus sylvestris L.) dans un environnement montagneux méditerranéen. La relation entre compétition et croissance a été étudiée dans quatre peuplements de Pinus sylvestris L. que l'on rencontre dans la zone continentale des montagnes méditerranéennes (dans la région de Guadarrama en Espagne). Ont été pris en compte un peuplement inéquienne, un peuplement avec du chêne (Quercus pyrenaica Willd.) en sous-étage, une plantation, et un peuplement équienne âgé. La compétition a été mesurée par un index indépendant, simple rapport taille/distance, et était corrélée négativement avec le diamètre des arbres. Cette corrélation négative était plus forte dans le peuplement inéquienne, la plantation et le peuplement équienne âgé que dans le peuplement avec sous-étage de chêne. L'index de compétition était aussi corrélé négativement avec l'accroissement courant en diamètre. La relation était modérément forte dans le peuplement équienne âgé et faible dans le peuplement inéquienne et la plantation. Dans le peuplement inéquienne et le peuplement équienne âgé une relation faiblement significative a été trouvée entre croissance en diamètre et taille de l'arbre, alors que ces paramètres n'étaient pas corrélés dans le peuplement avec sous-étage de chêne. L'index de compétition fournit une meilleure prédiction du taux de croissance que le simple diamètre. La croissance en diamètre et en surface terrière était plus importante dans le peuplement inéquienne que dans le peuplement équienne âgé.

compétition / croissance / pinus sylvestris / pin sylvestre / structure de peuplement

\section{INTRODUCTION}

Scots pine (Pinus sylvestris L.) is one of the preferred species for reforestation in Spain, where it occupies third place among the native conifers (920000 ha) and yields $7 \%$ of the total timber production. Average wood production is around 4 to $5 \mathrm{~m}^{3} \mathrm{ha}^{-1}$ year $^{-1}$, with wide site variations [4]. Such variability seems to be caused by structure, site quality, diseases and competition [7].

Scots pine is considered a shade-intolerant species, requiring much light for good development [23] and is unsuited to uneven-aged structure in Spain, although shading by retained trees can be helpful for regeneration [28], survival and growth [24]. In areas of continental climate, however, it behaves as a semi-shade-tolerant species and seedlings can tolerate some shading. Scots pine stands may be two-storied in sites with sufficient water supply. In some areas of Scotland, where there is no competition from other species and natu-

* Corresponding author: joseantonio.manzanera@upm.es ral disasters such as forest fire are rare, regeneration in small gaps takes place [17]. As a result, trees of different age classes may be found simultaneously in the same stand [12]. This may lead to a clumped spatial structure, such as that found in some other pine species, for example Pinus ponderosa Douglas ex Lawson \& C. Lawson [8], Pinus nigra Arn. [21] or P. cembra L. [24]. Currently, many forest managers actively pursue this structural variability because of the current social preference for diversity, whether in species, tree sizes or general stand structure [19].

There is, however, evidence that competition leads to reduced diameter increment in Scots pine stands [11]. Simple size ratio competition indices, such as that of Hegyi [9], explained over $50 \%$ of the variation in radial growth in Scots pine stands in Sweden [2].

The hypothesis of our work is that the current diameter growth of Scots pine is affected by competition in all types of stand structure. Therefore, the aim of this study is to characterise and compare competition-growth relationships in Scots pine stands of different structures. 
Table I. Stand area, climatic, topographic and soil type data of the four Scots pine stands studied.

\begin{tabular}{|c|c|c|c|c|c|c|c|}
\hline Stand & Stand area (ha) & $\mathrm{P}(\mathrm{mm})$ & PDP $(\mathrm{mm})$ & DD (months) & Slope $(\%)$ & Soil type & Altitude (m) \\
\hline Uneven-aged & 98 & 1160.5 & 269.3 & 2.3 & 25 & Haplustep & 1450 \\
\hline With oak understorey & 50 & 1328.5 & 319.3 & 1.9 & 16 & Haplustep & 1470 \\
\hline Plantation & 10 & 1049.2 & 240.2 & 2.9 & 15 & Haplustep & 1420 \\
\hline Even-aged & 12 & 1049.2 & 240.2 & 2.9 & 18 & Haplustep & 1495 \\
\hline
\end{tabular}

P: annual precipitation; PDP: precipitation during the dry period (May-September); DD: drought duration.

\section{MATERIAL AND METHODS}

This study was conducted in three public forests in the Guadarrama mountains, located about $60 \mathrm{~km}$ from Madrid. There, four types of Scots pine stand structure were studied: a mature, naturally regenerated even-aged stand, an uneven-aged stand, a stand with oak understorey (Quercus pyrenaica Willd.) and a plantation. All four stands were situated at altitudes of between 1400 and $1500 \mathrm{~m}$ (Tab. I). Soils are formed on siliceous substrate of granites and gneiss [5], presenting umbric or ochric epipedon and a deep cambic horizon. They are classified as Haplustepts [27]. Mean annual temperature is $9.4{ }^{\circ} \mathrm{C}$. Precipitation averages $1180 \mathrm{~mm}$ per year (Tab. I).

All the stands were first identified by photo-interpretation, visited by experts, and a representative area of each type of structure was delimited. In each of these representative areas of each stand structure two rectangular plots of $40 \mathrm{~m}$ by $60 \mathrm{~m}$ were chosen at random. In the plantation, only one plot was chosen given the smaller area and the greater homogeneity of the stand. Diameter at breast height (dbh, $1.3 \mathrm{~m}$ ) and total height were measured in all trees higher than $1.3 \mathrm{~m}$ inside the plots. The homogeneity between both plots was verified and the data were merged as one sample per stand. A total of 1209 trees were measured, 399 pine trees in the uneven-aged stand, 510 ( 251 oaks and 259 pine trees) in the stand with oak understorey, 170 pine trees in the plantation, and 130 pine trees in the even-aged stand.

For the variables age at breast height $(1.3 \mathrm{~m})$ and Current Diameter Increment in the last 5, 10 and 15 years (resp., CDI5, CDI10 and CDI15), a pilot sampling was previously carried out to keep sampling costs to a minimum. The measurement of these variables was restricted to Scots pine. Sample size for these variables was inferred assuming a sampling error of less than $9 \%$ as an objective, leading to a sampling size of 76 pine trees for the uneven-aged stand, 60 for the stand with oak understorey, 67 for the plantation and 41 for the evenaged stand. These pine trees were chosen by random sampling inside the plots. In each of these sampled trees, a wood core was extracted at a height of $1.3 \mathrm{~m}$ and annual radial increments were recorded. Also, the radius without bark was calculated for five-year periods. Current diameter increment (CDI) was estimated as twice the current radial increment; that is to say, twice the mean width of the last five (CDI5), 10 (CDI10) or 15 (CDI15) rings. Current basal area increment without bark was calculated as the difference between the present basal area and that of the previous five years, divided by five. The site index for Scots pine in the Guadarrama mountains $\left(H_{100}\right)$ was determined with Garcia and Gomez (1984) site index curves, based on dominant height $\left(H_{\text {dom }}\right)$, average height of the 100 tallest trees per hectare, at 100 years age. Site index was estimated for the uneven-aged stands by deducing the mean age of the dominant trees from their wood cores and assuming that Scots pine frequently grows in clumps or copses of about $200 \mathrm{~m}^{2}$ up to the age of 60 years or even more. These regeneration gaps behave like even-aged patches. The site index was then inferred from the Garcia and Gomez site index curves (1984).
The effect of competition was described by Lorimer's index [14], as modified by Vayreda et al. [29]:

$$
L M=\sum_{j} g_{j} / g_{i}
$$

Where $L M$ is the modified Lorimer area index; $g_{j}$ is the basal area of competitor $j ; j=1, \ldots, n ; n$ is the number of competitors within a certain distance; $g_{i}$ is the basal area of the subject tree. Distances between trees were calculated from relative Cartesian coordinates of each tree on the above-mentioned plots. A program was developed to calculate the basal area of the trees inside each neighbourhood radius and LM indices were calculated for increasing distances, $\mathrm{m}$ by $\mathrm{m}$, from 1 to $10 \mathrm{~m}$, and for 12.5 and $15 \mathrm{~m}$.

For the variables dbh, CDI5, CDI10, CDI15 and LM indices at distances from 1 to $15 \mathrm{~m}$, the relationship between pairs of variables was analysed, and the following regression models were fitted between each pair of variables: linear, double reciprocal, square root-Y, square root-X, exponential, S-curve, logarithmic, inverse-Y, inverse$X$, multiplicative, logistic and log probit regression model. The model with the best fit was selected and the $R$-squared statistic was calculated for each model and stand.

\section{RESULTS}

Dominant height and stand density parameters are shown in Table II. Tables III to VI display the statistically significant $R$-squared ( $p$-value $<0.01$ for the hypothesis that $R$-squared $=0$ ) between variables studied in the different stands. Age, height and diameter variables were strongly associated in both the uneven-aged stand and the stand with oak understorey, while these variables were only moderately associated in the plantation (data not shown). A range of ages was found in the plantation, as some retained trees were interspersed and natural regeneration from these older trees may have taken place. In the mature even-aged stand, dbh and height were strongly associated but the association between height and age was weaker, as all trees in this stand were from the dominant layer and variability was lower (data not shown).

Competition ( $L M$ index) was negatively associated with $\mathrm{dbh}$ in all stands, the effect being more pronounced at different distances among stands. In the uneven-aged stand, the $R$-squared was higher for $6 \mathrm{~m}$ distances or higher (more than 0.93 for dbh, Tab. III). In the stand with oak understorey, these relationships were stronger at neighbourhood radii of $10 \mathrm{~m}$ upwards, and ranging from a low $R$-squared of 0.06 for $1 \mathrm{~m}$ to an $R$-squared of 0.96 for $15 \mathrm{~m}$ (Tab. IV). In the plantation, dbh was strongly associated with competition at a distance of $6 \mathrm{~m}$ or more $(R$-squared $>0.8$, Tab. V). In the mature even-aged stand (Tab. VI), dbh was strongly associated with competition, 
Table II. Dominant height $\left(H_{\text {dom }}\right.$ : mean height of the 100 highest trees per ha), site index $\left(H_{100}=H_{\text {dom }}\right.$ at 100 years age, [6] $)$, mean age of the dominant trees, Stem number per ha $(N)$, mean distance between trees $\left(M D B T=100 \mathrm{~N}^{-1 / 2}\right)$ in $\mathrm{m}$, Relative $\operatorname{Spacing}\left(R S=100\left(H_{\mathrm{dom}} \times N^{1 / 2}\right)^{-1}\right)$ and basal area $(\mathrm{g})$ in $\mathrm{m}^{2} \mathrm{ha}^{-1}$ of four Scots pine stand structures located in the Guadarrama mountains.

\begin{tabular}{lccccccc}
\hline Stand & $H_{\text {dom }}(\mathrm{m})$ & $H_{100}(\mathrm{~m})$ & Mean dominant age $(\mathrm{yr})$ & $N\left(\right.$ Stem No. ha $\left.{ }^{-1}\right)$ & $M D B T(\mathrm{~m})$ & $R S$ & $\mathrm{~g}\left(\mathrm{~m}^{2} \mathrm{ha}^{-1}\right)$ \\
\hline Uneven-aged & 21 & 23 & 91 & 965 & $1400^{*}$ & 3.2 & 2.7 \\
With oak understorey & 19 & 17 & 124 & 703 & 0.15 & 34.9 \\
Plantation & 22 & 29 & 64 & 315 & 3.8 & 0.17 \\
Mature even-aged & 24 & 25 & 98 & $59.9^{\#}$ & 5.6 & 0.23 & 55.4 \\
\hline
\end{tabular}

* $N$ includes 581 pines and 819 oaks ha $^{-1}$; \# basal area $(\mathrm{g})$ of oaks was $0.93 \mathrm{~m}^{2} \mathrm{ha}^{-1}$.

Table III. Statistically significant relationships between diameter at breast height (dbh), current diameter increment of the last 5 (CDI5), 10 (CDI10) and 15 (CDI15) years and modified Lorimer's area indices for distances of 1 (LM1), 2 (LM2), 3 (LM3), 4 (LM4), 5 (LM5), 6 (LM6), 7 (LM7), 8 (LM8), 9 (LM9), 10 (LM10), 12.5 (LM12.5), and 15 (LM15) $\mathrm{m}$ in the uneven-aged stand.

\begin{tabular}{|c|c|c|c|c|c|c|c|c|c|c|c|c|c|c|c|}
\hline & CDI5 & CDI10 & CDI15 & LM1 & LM2 & LM3 & LM4 & LM5 & LM6 & LM7 & LM8 & LM9 & LM10 & LM12.5 & LM15 \\
\hline dbh $R$-squared & 0.13 & 0.17 & 0.18 & 0.17 & 0.42 & 0.58 & 0.53 & 0.68 & 0.94 & 0.96 & 0.97 & 0.98 & 0.99 & 0.99 & 0.99 \\
\hline$p$-value & 0.0001 & 0.0002 & 0.0002 & $<0.0001$ & $<0.0001$ & $<0.0001$ & $<0.0001$ & $<0.0001$ & $<0.0001$ & $<0.0001$ & $<0.0001$ & $<0.0001$ & $<0.0001$ & $<0.0001$ & $<0.0001$ \\
\hline CDI5 $R$-squared & & & & & 0.13 & 0.12 & 0.13 & 0.16 & 0.31 & 0.29 & 0.34 & 0.31 & 0.28 & & \\
\hline$p$-value & & & & & 0.004 & 0.007 & 0.008 & 0.005 & 0.0001 & 0.0004 & 0.0002 & 0.002 & 0.008 & & \\
\hline CDI10 $R$-squared & & & & & 0.14 & 0.12 & 0.15 & 0.14 & 0.22 & 0.20 & 0.21 & & & & \\
\hline$p$-value & & & & & 0.0026 & 0.006 & 0.005 & 0.008 & 0.002 & 0.004 & 0.005 & & & & \\
\hline CDI15 $R$-squared & & & & & 0.15 & 0.15 & 0.19 & 0.21 & 0.24 & 0.24 & 0.25 & 0.23 & & & \\
\hline$p$-value & & & & & 0.002 & 0.003 & 0.001 & 0.001 & 0.001 & 0.002 & 0.002 & 0.007 & & & \\
\hline
\end{tabular}

Table IV. Statistically significant relationships between diameter at breast height (dbh), current diameter increment of the last five years (CDI5), and modified Lorimer's area indices for distances of 1 (LM1), 2 (LM2), 3 (LM3), 4 (LM4), 5 (LM5), 6 (LM6), 7 (LM7), 8 (LM8), 9 (LM9), 10 (LM10), 12.5 (LM12.5), and 15 (LM15) $\mathrm{m}$ in the stand with oak understorey.

\begin{tabular}{|c|c|c|c|c|c|c|c|c|c|c|c|c|}
\hline & LM1 & LM2 & LM3 & LM4 & LM5 & LM6 & LM7 & LM8 & LM9 & LM10 & LM12.5 & LM15 \\
\hline dbh $R$-squared & 0.06 & 0.11 & 0.16 & 0.36 & 0.40 & 0.46 & 0.54 & 0.56 & 0.60 & 0.88 & 0.94 & 0.96 \\
\hline$p$-value & 0.0005 & $<0.0001$ & $<0.0001$ & $<0.0001$ & $<0.0001$ & $<0.0001$ & $<0.0001$ & $<0.0001$ & $<0.0001$ & $<0.0001$ & $<0.0001$ & $<0.0001$ \\
\hline CDI5 $R$-squared & & & & & & & & & & & 0.62 & \\
\hline
\end{tabular}

Table V. Statistically significant relationships between diameter at breast height (dbh), current diameter increment of the last 5 (CDI5), 10 (CDI10) and 15 (CDI15) years and modified Lorimer's area indices for distances of 1 (LM1), 2 (LM2), 3 (LM3), 4 (LM4), 5 (LM5), 6 (LM6), 7 (LM7), 8 (LM8), 9 (LM9), 10 (LM10), 12.5 (LM12.5), and 15 (LM15) $\mathrm{m}$ in the plantation stand.

\begin{tabular}{|c|c|c|c|c|c|c|c|c|c|c|c|c|c|}
\hline & CDI10 CDI15 & LM1 & LM2 & LM3 & LM4 & LM5 & LM6 & LM7 & LM8 & LM9 & LM10 & LM12.5 & LM15 \\
\hline dbh $R$-squared & 0.10 & 0.12 & 0.43 & 0.50 & 0.47 & 0.75 & 0.83 & 0.89 & 0.93 & 0.94 & 0.93 & 0.97 & 0.99 \\
\hline$p$-value & 0.0080 .0002 & $<0.0001$ & $<0.0001$ & $<0.0001$ & $<0.0001$ & $<0.0001$ & $<0.0001$ & $<0.0001$ & $<0.0001$ & $<0.0001$ & $<0.0001$ & $<0.0001$ & $<0.0001$ \\
\hline $\begin{array}{l}\text { CDI10 } R \text {-squared } \\
\quad p \text {-value }\end{array}$ & & & & $\begin{array}{c}0.14 \\
0.006\end{array}$ & & & & & & & & & \\
\hline $\begin{array}{l}\text { CDI15 } R \text {-squared } \\
p \text {-value }\end{array}$ & & & $\begin{array}{c}0.15 \\
0.003\end{array}$ & $\begin{array}{c}0.24 \\
0.0003\end{array}$ & $\begin{array}{c}0.18 \\
0.003\end{array}$ & $\begin{array}{c}0.20 \\
0.002\end{array}$ & $\begin{array}{c}0.26 \\
0.0006\end{array}$ & $\begin{array}{c}0.20 \\
0.0067\end{array}$ & & & & & \\
\hline
\end{tabular}

Table VI. Statistically significant relationships between diameter at breast height (dbh), current diameter increment of the last 5 (CDI5), 10 (CDI10) and 15 (CDI15) years and modified Lorimer's area indices for distances of 2 (LM2), 3 (LM3), 4 (LM4), 5 (LM5), 6 (LM6), 7 (LM7), 8 (LM8), 9 (LM9), 10 (LM10), 12.5 (LM12.5), and 15 (LM15) $\mathrm{m}$ in the mature even-aged stand.

\begin{tabular}{|c|c|c|c|c|c|c|c|c|c|c|c|c|c|c|}
\hline & CDI5 & CDI10 & CDI15 & LM2 & LM3 & LM4 & LM5 & LM6 & LM7 & LM8 & LM9 & LM10 & LM12.5 & LM15 \\
\hline dbh $R$-squared & 0.22 & 0.25 & 0.34 & 0.34 & 0.28 & 0.38 & 0.67 & 0.82 & 0.89 & 0.88 & 0.91 & 0.90 & 0.95 & 0.99 \\
\hline$p$-value & 0.0029 & 0.0011 & 0.0001 & $<0.0001$ & $<0.0001$ & $<0.0001$ & $<0.0001$ & $<0.0001$ & $<0.0001$ & $<0.0001$ & $<0.0001$ & $<0.0001$ & $<0.0001$ & $<0.0001$ \\
\hline CDI5 $R$-squared & & & & & & 0.27 & 0.32 & 0.36 & 0.34 & 0.36 & 0.55 & 0.55 & & \\
\hline$p$-value & & & & & & 0.0044 & 0.0029 & 0.002 & 0.005 & 0.0086 & 0.0011 & 0.0015 & & \\
\hline CDI10 $R$-squared & & & & 0.36 & 0.35 & 0.31 & 0.45 & 0.55 & 0.51 & 0.54 & 0.61 & 0.59 & & \\
\hline$p$-value & & & & 0.0004 & 0.0006 & 0.0022 & 0.0002 & 0.0001 & 0.0003 & 0.0006 & 0.0004 & 0.0008 & & \\
\hline CDI15 $R$-squared & & & & 0.44 & 0.44 & 0.43 & 0.53 & 0.61 & 0.58 & 0.61 & 0.63 & 0.61 & & \\
\hline$p$-value & & & & 0.0001 & 0.0001 & 0.0002 & $<0.0001$ & $<0.0001$ & 0.0001 & 0.0001 & 0.0003 & 0.0006 & & \\
\hline
\end{tabular}




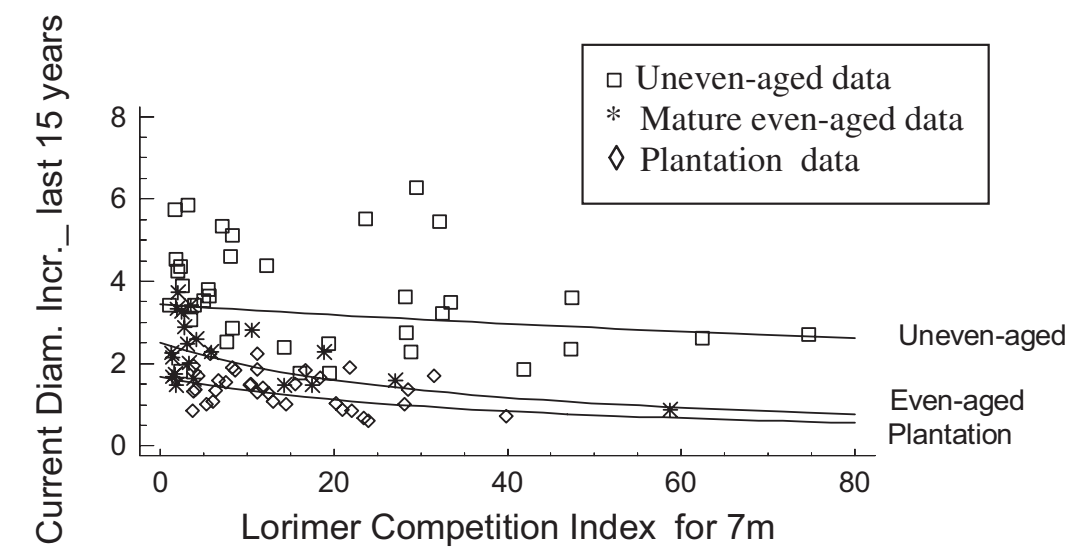

\begin{tabular}{lccc}
\hline Stand & \multicolumn{1}{c}{ Regression model } & $R$-squared & $p$ \\
\hline Uneven-aged & CDI15 $=1 /(0.290963+0.00113927 \times$ LM7 $)$ & 0.24 & 0.0015 \\
Mature even-aged & CDI15 $=1 /(0.399624+0.0112507 \times$ LM7 $)$ & 0.57 & 0.0001 \\
Plantation & CDI15 $=1 /(0.596557+0.014697 \times$ LM7 $)$ & 0.20 & 0.0067 \\
\hline
\end{tabular}

Figure 1. Adjusted regression models between the current diameter increment of the last 15 years (mm year ${ }^{-1}$ ) and the modified Lorimer's competition index at a distance of $7 \mathrm{~m}$ of the uneven-aged, mature even-aged and plantation stands. The real values in the scatter plot are represented by squares ( $\square)$ in the uneven-aged stand, stars $(*)$ in the mature even-aged stand, and diamonds $(\diamond)$ in the plantation.

with stronger coefficients for distances of $6 \mathrm{~m}$ or more $(R$ squared up to 0.99 ).

In the stand with oak understorey, no significant relationship was found between growth and size of pine trees (Tab. IV). In contrast, both in the uneven-aged and the mature even-aged stands, growth was significantly associated, although weakly, with size (Tabs. III and VI). In the plantation, only CDI10 and CDI15 were weakly associated with dbh (Tab. V).

Current diameter increment of the last 5, 10 and 15 years was negatively associated with the $L M$ index for distances up to $10 \mathrm{~m}$ in the uneven-aged stand; a small amount of variation was explained by the model ( $R$-squared up to 0.34 for CDI5 at $8 \mathrm{~m}$ distance, Tab. III). No significant relationship was found between diameter growth and competition indices for longer distances. Similar results were obtained in the mature evenaged stand, with moderately stronger associations $(R$-squared up to 0.63 for CDI15 and LM9, Tab. VI). Competition indices up to a distance of $7 \mathrm{~m}$ were also significantly associated in the plantation with CDI15 ( $R$-squared 0.26 for a $6 \mathrm{~m}$ distance, Tab. V), while CDI10 was only weakly associated with LM3 (Tab. V). In contrast, growth showed no significant relationship with competition in the stand with oak understorey, except for CDI5 and LM12.5 (Tab. IV).

Regression models adjusted between current diameter increment $(C D I)$ and competition index $(L M)$ were compared for the uneven-aged, the even-aged and the plantation stands, i.e., CDI15 vs. LM7 (Fig. 1). The stand with oak understorey had no significant model to be compared with other stands and was not included. In all cases, CDI of the uneven-aged stand is greater than that of the plantation and the even-aged stand. The same is true for the growth (i.e., CDI10) vs. dbh model (Fig. 2). Furthermore, the estimated stand-level basal area in- crement of the uneven-aged stand is greater than that of all the other stands (Tab. VII), although the basal area in the unevenaged stand is lower than in the plantation and the mature evenaged stand (Tab. II).

\section{DISCUSSION}

Climate and site conditions of all four stands were similar (Tab. I), although site index $\left(H_{100}\right)$ differences were observed between stands (Tab. II). This may influence growth, along with other forestry-related factors such as stand structure and competition. In other species, a relationship has been found between the radial increment of the stem and the site index $[3,18,22]$. Specifically, $H_{100}$ of the stand with oak understorey was lower than $H_{100}$ of the other stands, but dominant trees were also older than those in the other stands; this suggests a potential problem with the site index curves, the age measurement, or an interaction with the oak understorey.

As expected, a significantly negative relationship between competition and size was observed in all the stands. However, growth was in general weakly associated to size, with different patterns between the stands. The growth of larger and taller trees was faster in the uneven-aged stand, the plantation and the mature even-aged stand. This behaviour may be interpreted as a search for light and dominance by the larger trees following an asymmetric competition pattern [26]. In contrast, in the stand with oak understorey, growth was not associated with size. This may be attributed either to senescence of the larger pine trees or to symmetric competition, i.e., the effect of competition is the same on older, larger trees as on younger, smaller trees [26]. In this type of competition, the oak understorey may have played a role. 


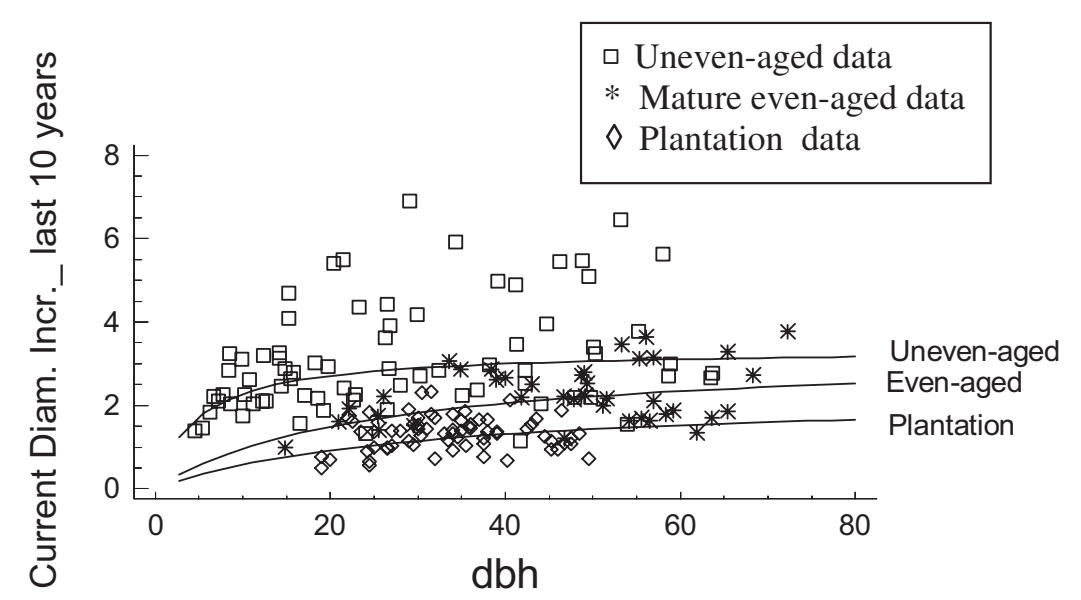

\begin{tabular}{lccc}
\hline Stand & Regression model & $R$-squared & $p$ \\
\hline Uneven-aged & CDI10 $=\exp (1.26553-3.83567 / \mathrm{dbh})$ & 0.17 & 0.0002 \\
Mature even-aged & CDI10 $=1 /(0.305529+7.29771 / \mathrm{dbh})$ & 0.25 & 0.0011 \\
Plantation & CDI10 $=1 /(0.443136+12.7741 / \mathrm{dbh})$ & 0.10 & 0.008 \\
\hline
\end{tabular}

Figure 2. Adjusted regression models between the current diameter increment of the last 10 years $\left(\mathrm{mm}^{-1} \mathrm{ear}^{-1}\right)$ and the diameter at breast height $(\mathrm{dbh}, \mathrm{cm})$ of the uneven-aged, mature even-aged and plantation stands. The real values in the scatter plot are represented by squares $(\square)$ in the uneven-aged stand, stars $(*)$ in the mature even-aged stand, and diamonds $(\diamond)$ in the plantation.

Table VII. Current basal area increment without bark $\left(\mathrm{m}^{2} \mathrm{ha}^{-1}\right.$ year $\left.^{-1}\right)$ in four stand structures. Current basal area increment was calculated as the difference between the present basal area and that of the previous five years, divided by five.

\begin{tabular}{lcccccccc}
\hline Stand structure & \multicolumn{7}{c}{ Current basal area increment $\left(\mathrm{m}^{2} \mathrm{ha}^{-1}\right.$ year $\left.^{-1}\right)$} \\
\cline { 2 - 8 } & \multicolumn{7}{c}{ Diameter class $(\mathrm{cm})$} & \\
\cline { 2 - 8 } & $<10 \mathrm{~cm}$ & $10.1-20$ & $20.1-30$ & $30.1-40$ & $40.1-50$ & $50.1-60$ & $>60 \mathrm{~cm}$ & TOTAL \\
\hline Uneven-aged & 0.09 & 0.11 & 0.08 & 0.12 & 0.19 & 0.08 & 0.01 & 0.68 \\
With oak understorey & 0.02 & 0.03 & 0.06 & 0.07 & 0.10 & 0.05 & 0.33 & 0.57 \\
Plantation & & 0.01 & 0.17 & 0.26 & 0.13 & 0.13 & 0.07 \\
Mature even-aged & & 0.00 & 0.02 & 0.05 & 0.08 & 0.35 \\
\hline
\end{tabular}

Lorimer [14] reported that for predicting growth in natural even-aged hardwood stands distance-dependent measures of competition are not superior to distance-independent measures. Most of the comparisons between distance-dependent and distance-independent individual tree growth models do not report the expected differences in prediction ability [25]. Martin and Ek [16] also found the same result in uniform red pine plantations, concluding that distance-independent competition indices are more accurate for diameter growth projections in managed plantations, where location is of lesser importance. Vayreda et al. [29] compared several competition indices in two Scots pine stands in relation to the radial growth in the last five years and found that the modified Lorimer index performed better than all other indices tested. It is noteworthy that the Hegyi index, which takes into account distance to competitors, was no better than the modified Lorimer index, which does not include distance in its formula. Simple size ratio indices performed as well or better in their correlation with annual diameter growth than more complex indices, such as space, area overlap, and root/crown indices [10]. In con- trast, Biging and Dobbertin [1,2] obtained better results with estimated crown parameters. Our results show that the modified Lorimer index provides a substantially better prediction of growth rate than the alternative size parameters, such as dbh, in all the stand structures studied, especially in the mature evenaged stand.

The negative relationship between $C D I$ and the $L M$ index in all stands except for that with oak understorey may be interpreted as a hint of the negative effect of competition on growth when stand density is very high. At present, the low values of this relationship suggest that stand density is not so high as to cause serious growth limitation. The neighbourhood radius for maximum significant influence of competition on diameter growth was $8 \mathrm{~m}$ in the uneven-aged stand and $10 \mathrm{~m}$ in the mature even-aged stand. No relationship was found between CDI5 and $L M$ indices in the plantation, as a result of thinning during the last 10 years in this stand. In contrast, competition influenced Scots pine stem growth in other situations [15].

In our study, we observed a greater diameter growth in the uneven-aged stand than that in the mature even-aged stand and 
the plantation for the same competition index. This result must be viewed with caution, given the small sample size. Nevertheless, other authors have reported that multiaged stands maintain comparable levels of timber productivity over time with even-aged stands [19], and Lähde et al. [13] observed higher productivity for uneven-sized stands of Scots pine in Finland. O'Hara and Nagel [20] also found that uneven-aged ponderosa pine stands were more efficient structures for maximizing the reception of sunlight than even-aged stands where the level of competition for available light and moisture was higher. In fact, even-aged stands had lower soil moisture availability per transpiration rate and a greater amount of water stress, which limits gas exchange and photosynthesis more than in multiaged structures [20].

\section{CONCLUSIONS}

The relationship between current diameter growth and competition was characterised in four stand structures of Scots pine, and an analysis was made of the variables influencing this relationship in a mountain area with a continental Mediterranean climate, i.e., in the Guadarrama range (Spain). The modified Lorimer competition index was successfully used to predict growth rate in both uneven-aged and even-aged stands. Taking into account the limited number of stands studied, no general conclusions can be drawn from the effect of stand structure on growth. Nevertheless, our results suggested a greater diameter and basal area growth of Scots pine in the uneven-aged stand than in the even-aged stand and the plantation. Additional research using this kind of approach might be warranted, and the effects on stand-level volume increment might also be considered. At densities that do not limit diameter growth, the uneven-aged stand maintains a continuous cover, a microclimate and is compatible with sustainable production. The conservation of a continuous cover and an irregular structure by means of moderate wood extractions for short periods is advisable for protection of the ecosystem and for aesthetic or social purposes.

Acknowledgements: This research work was supported by the D.G. de Investigación, Consejería de Educación y Cultura de la Comunidad de Madrid (project GR/AMB/0267/2004). We also thank Luis Orofino, Pablo Orofino, Jaime Hernandez, Alvaro Sanchez, Maria Estirado, Alvaro Ruiz, Elena Sanchez, Tania Lopez, Tania Caballero and Vanesa Jalvo for their assistance in field work and data processing, and to Pru Brooke-Turner for the linguistic revision of the manuscript.

\section{REFERENCES}

[1] Biging G.S., Dobbertin M., A comparison of distance-dependent competition measures of height and basal area growth of individual conifer trees, For. Sci. 38 (1992) 695-720.

[2] Biging G.S., Dobbertin M., Evaluation of competition indices in individual tree growth models, For. Sci. 41 (1995) 360-377.

[3] Castedo-Dorado F., Dieguez-Aranda U., Alvarez-Gonzalez J.G., A growth model for Pinus radiata D. Don stands in northwestern Spain, Ann. For. Sci. 64 (2007) 609-619.

[4] Diéguez-Aranda U., Álvarez-González J.G., Barrio-Anta M., RojoAlboreca A., Site quality equations for Pinus sylvestris L. plantations in Galicia (northwestern Spain), Ann. For. Sci. 62 (2005) 143152.
[5] Gandullo J.M., Nicolas A., Ecología de los pinares españoles. Ministerio de agricultura, I.F.I.E., Madrid, 1969.

[6] Garcia-Abejon J.L., Gomez-Loranca J.A., Tablas de producción de densidad variable para Pinus sylvestris L. en el Sistema Central, INIA, Madrid, 1984.

[7] Gonzalez S.C., Bravo F., Inventario y descripción de la regeneración natural. Aplicación a grupos ordenados de pino silvestre (Pinus sylvestris L.) del Alto Ebro (Burgos), Montes 50 (1997) 21-28.

[8] Harrod R.J., McRae B.H., Hartl W.E., Historical stand reconstruction in ponderosa pine forests to guide silvicultural prescriptions, For. Ecol. Manage. 114 (1999) 433-446.

[9] Hegyi F., A simulation model for managing jack-pine stands, in: Fries J. (Ed.), Growth model for tree and stand simulation, Royal Coll. For., Stockholm, Sweden, 1974, pp. 74-90.

[10] Holmes M.J., Reed D.D., Competition indices for mixed species Northern hardwoods, For. Sci. 37 (1991) 1338-1349.

[11] Jäghagen K., Albrektson A., Induced competition among Scots pine seedlings and its effect on future timber quality, New For. 12 (1996) 163-174.

[12] Kuper J.H., Sustainable development of pine forests, Misc. Papers Wageningen University, 1994.

[13] Lähde E., Laiho O., Norokorpi Y., Saksa T. Structure and yield of all-sized Scots pine dominated stands, Ann. Sci. For. 51 (1994) $111-120$.

[14] Lorimer C.G., Test of age-independent competition indices for individual trees in natural hardwood stands, For. Ecol. Manage. 6 (1983) 343-360.

[15] Mäkinen H., Effect of intertree competition on biomass production of Pinus sylvestris (L.) half-sib families, For. Ecol. Manage. 86 (1996) 105-112.

[16] Martin G.L., Ek A.R., A comparison of competition measures and growth models for predicting plantation red pine diameter and height growth, For. Sci. 300 (1984) 731-743.

[17] Nixon C.J., Composition, structure and regeneration of tree species within Scotland's native pinewoods, in: Olsthoorn A.F.M. (Ed.), Management of mixed-species forests: silviculture and economics, IBN Scientific Contributions 15, IBN-DLO, Wageningen, 1999, pp. 191-198.

[18] Nutto L., Spathelf P., Rogers R., Managing diameter growth and natural pruning of Parana pine, Araucaria angustifolia (Bert.) $\mathrm{O}$ Ktze., to produce high value timber, Ann. For. Sci. 62 (2005) 163173.

[19] O'Hara K.L., The Silviculture of transformation - a commentary, For. Ecol. Manage. 151 (2001) 81-86.

[20] O'Hara K.L., Nagel L.M., A functional comparison of productivity in even-aged and multiaged stands: a synthesis for Pinus ponderosa, For. Sci. 52 (2006) 290-303.

[21] Oldeman R.A.A., Forests: Elements of silvology, Springer, Heidelberg, 1990.

[22] Sanchez-Gonzalez M., Tomé M., Montero G., Modelling height and diameter growth of dominant cork oak trees in Spain, Ann. For. Sci. 62 (2005) 633-643.

[23] Schütz J.P., Sylviculture 1. Principles d'éducation des forêts, Presses Polytechniques et Universitaires Romandes, Lausanne, 1990.

[24] Schütz J.P., Sylviculture 2. La gestion des forêts irrégulières et mélangées, Presses Polytechniques et Universitaires Romandes, Lausanne, 1997.

[25] Soares P., Tomé M., Distance-dependent competition measures for eucalyptus plantations in Portugal, Ann. For. Sci. 56 (1999) 307319.

[26] Stoll P., Weiner J., Schmid B., Growth variation in a naturally established population of Pinus sylvestris, Ecology 75 (1994) 660-670.

[27] USDA, Keys to soil taxonomy, 8th ed. 1998.

[28] Valkonen S., Effect of retained Scots pine trees on regeneration, growth, form, and yield of forest stands, Investigación Agraria: Sistemas y Recursos Forestales: Fuera de serie 1 (2000) 121-145.

[29] Vayreda J., Burriel J.A., Raventos J., Gracia C., Variabilidad en el crecimiento de Pinus sylvestris en función de su edad y tamaño y de la competencia local, Studia Oecologica 10/11 (1994) 373-384. 